\title{
COLLABORATIVE MANAGEMENT AND ORGANISATIONAL RESILIENCE: EVIDENCE FROM THE OIL AND GAS INDUSTRY OF A DEVELOPING ECONOMY
}

\author{
ACHEBELEMA, Tokoni Christiana \\ University of Port Harcourt Business School, \\ Port Harcourt, Rivers State, Nigeria. \\ tkoachebbs@gmail.com \\ \& \\ ACHEBELEMA, Sam Damiebi \\ Department of Management, \\ Ignatius Ajuru University of Education, \\ Rumuolumeni, Rivers State, Nigeria.
}

\begin{abstract}
This study examined the link between collaborative management and organizational resilience in the oil and gas industry in Rivers State. The quasi-experimental and crosssectional research designs were adopted. The population is made of 72 managers, supervisors, and HODs of oil and gas firms in Rivers State. The census technique was used for the sampling since the population is relatively small. The Spearman's Rank Order Correlation Coefficient (Rho) was used for the analysis with the aid of SPSS. It was concluded that a sound leadership climate can change the direction of any organization towards achieving its stated goals. This means a good leadership climate could induce highlevel firm alliance. Organizational leadership climate is a composition variable that can be brought to bear in proffering varying solutions to the underlying issues in any organization. The outcome of this study resulted in the following recommendations: Collaborative management encourages positive bahaviours towards robustness. Hence, management ought to take decisional actions to increase awareness and improve productivity towards developing timely diverse solutions in handling organizational challenges. Collaborative management improves top-level decision-making to enhance resourcefulness. Therefore, management should encourage employees to make personal decisions about the disturbances and complex problems they face in their job towards preserving their position in the industry. Organizational leadership should build a climate designed to encourage robustness and resourcefulness as that will induce the needed growth towards its desired heights to foster resilience.
\end{abstract}

Keywords: Collaborative Management, Organisational Resilience, Robustness, Resourcefulness, and Oil and Gas Industry. 


\section{Introduction}

Nigeria is perceived as the largest producer of oil and gas in Africa. Her oil exploration started in 1903 (Thomas, 1995). At this time, Nigeria Bitumen Corporation was responsible for conducting exploratory activities/works in smaller quantities. These exploratory activities suffered setbacks because technological, financial, and material resources/provisions were deficient (Jeremiah, 2019). Consequently, multinational oil and gas firms then took over the exploration of oil in large scale and commercial quantity. However, D'Arcy Exploration Company and Whitehall Petroleum reverted their operation licenses in 1923 after their failed attempt at oil exploration. Subsequently, in 1937, Shell D'Arcy Petroleum Development Company of Nigeria started exploratory works after they were allotted an operational license covering 9200,000 square kilometers. Afterward, the Consortium was issued a license of oil exploration to explore oil across Nigeria in 1951 leading to the commencement and review of drilling activities (Thomas, 1995). Similarly, Frynas (1999) pointed out that the intensity of oil exploration after 1951 culminated in the discovery of crude oil in Oloibiri by Shell-BP in 1956, and also in Afam and Bomu in Ogoni land. Even so, oil production officially began in 1957, and in 1960, when Nigeria exported about 847, 000 tonnes of it. The huge profit and other accruals from oil exploration lured other Non-British organizations into the business here in Nigeria. These firms include; Mobile, Tenneco, Gulf Oil, Chevron, Agip, and Elf, and were granted operational exploration licenses between 1955 and 1962. It is imperative to take cognizance of the fact that, of the six petroleum exportation terminals present in Nigeria, Shell owns two, while Agip, Texaco, Chevron, and Mobil own one each.

Fast forward to the year 2000, crude exports accounted for over $98 \%$ of earnings on exports, representing $83 \%$ of Federal Government Revenue. This boosted the GDP of Nigeria to about $14 \%$ because oil exports then provide about $95 \%$ of forex earnings, and $65 \%$ budgetary revenue of the government. Nigeria's oil energy reserves were then estimated between 16, 22, and 36.5 billion barrels, which ranked Nigeria as the 10th most petroleum-rich and prosperous economy in Africa. However, recent realities reveal that the industry seems to have had some setbacks, attributed to several risk dynamics like: (1). Regulatory and legislative changes, (2). Increase in regulatory cost of compliance, (3). Operational hazards wish may include blowouts, oil spills, and personal injury, (4). General industry competition, (5). Environmental restrictions and regulations, (6). The decrease in demand, (7). The increased cost of operation, etc. These factors appeared to have bedeviled the industry resulting in, (a). Volatile prices, (b). Inability to expand reserves or find replacement reserves and/or inaccurate reserve estimates, (c). Inadequate liquidation or access to capital, (d). Indebtedness, (e). Inadequate or unavailable insurance coverage, (f). Shortage of rigs, equipment, and qualified personnel (International Energy Agency [IEA], 2019). More so, research experts have fingered the seeming absence of firm resilience as a pivotal indicator of the downward slope in the industry (Somers, 2009; Lengnick-Hall \& Beck, 2009)

Interestingly, Umoh, Amah, and Wokocha (2014) had argued that building resilient organizations helps lessen/eliminate firms/businesses' exposure to environmental threats and hazards by putting self-protective measures in place to antedate and overrun the odds and consequence disruptive occurrence senses. They maintained that preventing possible environmental intricacies entails responding swiftly and with precision when an event occurs, and by recuperating as briskly and wholly as possible. On this basis, Sutcliffe and Vogus (2016) assert that resilience at either individual organizational level is generally hinged on the idea of peak performance, even amidst difficult circumstances with an apparent threat to jeopardize chances of high performance. Also, Madni (2007) views resilience as the 
propensity to expect an unsettling situation, and counterattack such situations by adjusting to it, and then pull through by restoring normalcy in time. More so, Tende, Achebelema, and Kpurubu (2018) hold the view that resilience boosts firms' proficiency in anticipating, strategizing for, adjusting to, and influencing environmental changes and complexities posing as a threat for its good, with recourse to surviving and thriving. Resilience helps to instill tenacity and perseverance because every shade of change (especially externally triggered) that threats organizations call for matches resilience to deal with. And collaborative management could prove useful with regards to boosting resilience.

To build a formidable team of motivated staff where communication level is smooth and effective communication amongst employees working together, collaborative management is the right tool; because it allows for a level playing field where staffs freely express themselves on organizational issues (Hurley, 2011). It enhances/expedites actions and cooperation, with emphasis on appreciating the various creative and innovative methods available in tackling challenges, thereby improving management practices of firms (Mark, 2016). On this note, Powell, Koput, Smith-Doerr, and Owen-Smith (1999) observed that collaborative management helps management and staff see the worthwhile differences and helps them observe how to act in varying situations. Likewise, Sanagha and Aronson (2009) revealed that collaborative management creates mindfulness about a possible conflict between collaborating workforce and units which makes for a mutually advantageous relationship. To further buttress this point, collaborative management tends to allow for "goal congruence," as it makes room for critical thinking and work teams brainstorming, and offers various outlooks towards arriving at apt solutions. Similarly, Thomson, Perry, and Miller (2007) noted that collaborative management tends to promote self-analysis, problem-solving, makes one look at a bigger picture, and helps in creating room for learning. By implication, collaborative management helps in pooling talents and strengths, developing employees' skills, expedite solutions, increases adeptness, and improves employee retention, job excitement, and satisfaction.

In today's world of business, oil and gas firms (particularly in the Niger Delta region of Nigeria) are constantly battling to survive because of the various challenges connected to social responsibility, evident in the several communal clashes/crises, and disagreement on matters of employment, etc. highlighting the need for organizational resilience in the industry. Consequently, the framework below was designed to examine the affiliation concerning collaborative management and organizational resilience. The predictor (or independent) variable being collaborative management has governance, autonomy, mutuality, and norms, adopted from Tierney (2003), as its dimensions namely; while the criterion variable being organizational resilience owes its measures - robustness and resourcefulness to Thomson, Perry, and Miller (2007). However, the researcher chooses to adopt leadership climate as a possible moderator of the nexus between the constructs, in the quest to access issues relating to non-resilience.

Having been initially established in the background, highly volatile prices, escalating global demand, and the hike in harsh environmental challenges are three of the most pressing issues currently bedeviling Nigeria's oil and gas industry. On the environment, the need to protect the environment and its attendant encumbrances has been a source of worry to private investors, non-governmental and not-for-profit organizations, and successive governments. Various laws and regulations are churned out to regulate the activities of oil companies that have recently led to alarming levels of environmental degradation. Lack of attention on the part of these firms has worsened environmental issues all over the nation and Rivers State in 
particular, leading to land degradation; inability to conserve soil, forest products, nature, and natural protected area; inability to manage water resources, coastal areas, waste and sanitation; and other issues bothering on afforestation, deforestation, and desertification, etc.

Proposing Nigerian national law and regulation relating to the environment dates far back to 1950 when the issues of environmental pollution trapped the interest of the colonizing authorities. Starting from that time, more than a few regulations, laws, and enforcing agencies have been set up. Thus, the outcome of the internal convention held to prevent sea pollution in 1954 was the passing of the Oil Navigable and water Acts 1968. And it happens to be the most encompassing legislation on oil pollution, and the existence of NOSDRA (National Oil Spill Detection and Response Agency) was established through Act 15, 2006. The Agency was established as a portion of the general plan to bring about a strong, healthy, and spotless environment in Nigeria mainly in Rivers State. This has tremendously affected the activities of oil and gas firms to the point where they even fail to resist challenges of rising international demands, highly fickle prices and increasing inflexible environmental laws and regulation.

To this end, suffice to argue that the lack of resilience of oil and gas firms could be curbed through the decrease of costs to remain competitive, improve performance to guarantee the valorization of assets, improve environmental footprint to meet tough standards through collaborative management.

\section{Theoretical Framework}

The baseline theories for this research are resource-based view (RBV) theory. Thriving is a helpful concept that subsists as a continuum. Haight et al. (2002) labeled the positive end of Thriving as self-actualization, where individuals have crowning experiences. A thriving person is living life to the fullest. Along this continuum, individuals breed and improve at diverse rates and in dissimilar ways based on exchanges with the environment and the enduring development of self. Thriving is fluid and all factors that influence Thriving continually change and interact. The ability to change fluidly accommodates the life span and the environmental factors that influence the life span. The factors continuously change and influence each other, and the resulting gestalt is the person who either thrives or does not thrive. The three interacting factors in a Thriving continuum are the person, the human environment, the nonhuman environment.

Each of these factors is ongoing, dynamic, and continually changing as the human and nonhuman environments affect each other. Elements of the human environment, the variety of humans who enter in and out of the person's environment at different phases of life, can either manipulate the environment and person to contribute to optimum growth or interfere with the environment to hinder thriving and growth. Contributing humans may be family members, friends, professionals, or others. At birth, there are parents, doctors, and nurses in an environment that should be conducive to thriving. During adulthood, humans interact with a growing family, work, and social connections. For older adults in nursing homes, caregivers represent important elements of the human environment. Each member of the human environment may have a negative or positive impact on an individual. As life progresses chronologically, there can be burgeoning growth as the individual grows and thrives or there can be a lack of growth or a failing caused by negative humans and a negative environment. The important traits of Thriving echo those of FTT-social relatedness and physical/cognitive function. However, in the Thriving Theory, physical/cognitive function encompasses physical function and cognitive/affective function. On the positive side of the 
continuum of Thriving, social relatedness becomes a connectedness with involvement, attachment, and a sharing of self. As the person thrives, there is an increased ability to care for oneself and to maintain optimal weight. In the cognitive/affective function, there is an improved mood state and a meaning to life, with the individual having a clear cognitive ability. Interpersonal ties, individuality, pride, engagement, and self-care are defined as the previous circumstances of Thriving in older adults. Key attributes of Thriving are defined as social connectedness, ability to find environment, adaptation to physical patterns, and positive cognitive/affective function. Consequences of Thriving are identified as medical, social, and psychological resilience.

\section{Meaning of Collaborative Management}

Collaborative management entails bringing collective intelligence to bear in delivering desired outcomes across organizational boundaries when simple mechanisms of control are lacking. It is rooted in the belief that when it has to do with tackling the kinds of novel, complex and multi-faceted challenges encountered by contemporary organizations; all of us could be more competent, creative, and smarter than any of us alone. It demands that leaders employ the power of influence rather than positional authority to engage and align people, focus their teams, sustain momentum, and perform. Here, success is a function of a workplace that breeds trust, mutual respect, and shared aspiration in which everyone can freely and maximally offer ideas to achieve collective goals. As a modus operandi, managers must through high-quality conversation, pay keen attention to both relationship and result (Hurley, 2011). This, however, could be a challenge for leaders known to have achieved several milestones through the exertive/authoritative leadership model. This, of course, is not unconnected to the fact that most leaders (especially at top levels) lack training on how to employ collaborative management in their organizations. Worst still, the culture and reward systems in most organizations discourage collaboration. Consequently, the need to build leaders' collaborative capacity must work in tandem with the creation of a collaborative organizational culture. According to Hurley (2011), while this appears to be an incredibly challenging task, its vital role in business success cannot be downplayed.

\section{Meaning of Organizational Resilience}

Resilient organizations are firms that can always foresee external and internal threats to their growth/survival, and proactively reposition/re-strategize to subvert and make the most from such threats (Giezen, 2013). It is more concerned with being proactive rather than being reactive. In other words, an organization is resilient when it can anticipate turbulences and take urgent steps to better position itself not to be dragged down by the foreseen disturbances (Holling, 1973). More so, a resilient organization can bounce back in the event of being hit by an unforeseen crisis (Gallopin, 2006). This implies that, while organizations are expected to be watchful and be on guard to not allow a crisis to hit them by being proactive, they are also expected to have the capacity to respond positively if hit by any crisis. Also, whether it is in anticipation of a future dynamic or in response to being rocked by unforeseen circumstances, resilient organizations must be capable of reinventing their entire process and methods of operation (Capano \& Woo, 2016; McManus, 2008). Furthermore, to forestall disruptions, respond to prevailing shocks and be capable of holistically re-strategize company operations during a crisis, an organization will depend on other organizations' resilience, the resilience of its workers, that of the industry it belongs to, the environment/stakeholders, and country at large. This implies that business' resilience is tied to other organizations' resilience within the same industry. More so, the resilience of the stakeholders of an organization (both 
external and internal) like government, suppliers, customers, shareholders, rivals, etc., also determines the resilience of the organization (Emmitt, 2010; Lengnick-Hall et al., 2011).

Robustness: There is a consensus amongst scholars as to robustness being a core feature of resilience. Derived from Physics, robustness could be described as a system that quickly returns to its original state after an uneasiness. The concept is inherent in various other subdisciplines such as supply chain, design strategy, systems engineering, quantitative models, etc. In the field of management, the concept refers to the capacity of a firm to bear up tension and avert dysfunction. Precisely, robustness is about bringing an organization's vulnerability down to the barest minimum, handling turbulent/stressful situations, and bouncing back if/when affected by such situations (Annarelli, \& Nonino, 2016). Organizations employ robustness as a kind of strategy to deal with instability from the external environment. A firm is robust when it is capable of taking in convolutions and harsh conditions by plummeting their susceptibilities to environmental dangers, handling unanticipated hitches, and recovering from the turbulence. A robust organization is proactive and not reactive. This type of organization can endure and withstand hardship, and remain stable in the face of difficulties. Robust organizations can anticipate danger before it takes place (Weir \& Laing, 2001). The robustness of an organization is a function of six features, which are: alignment, roles and responsibility, execution, prioritization, interaction and synergies, and leadership. Alignment implies organization members being fully abreast of their organization's long-term goals and feeling collectively responsible for aiding in the attainment of the goals. Roles and responsibilities deal with the allocation of vital and lucid roles/responsibilities and provide supportive procedures ad systems.

Resourcefulness: From an individual perspective, resourcefulness implies being able to personally/consciously regulate and channel one's behaviour towards coping with challenging and uneasy situations adequately. A resourceful organization forges ahead with their plans irrespective of the challenges they face (Harris, Artis, Waters \& Licata, 2006). More so, it entails achieving more with fewer resources, doing things right - being efficient. Resourceful organizations can set structure, cultures, and processes in place that will give them a competitive edge over others amid challenges (Licata, Mowen, Harris \& Brown, 2003). Resourcefulness comes in handy where there is a shortage in resources and in threatening situations or opportunities (Ashill, Rod, Thirkell \& Corruthers, 2009). The basic idea with resourcefulness is beyond just coping with difficulties, it also entails repositioning to identify opportunities in a storm and making the most of it with minimal resources. Resourceful organizations are run by leaders with a strong mental capacity to cope and adapt to complexities. Such leaders are said to possess cognitive, affective, and action-oriented competencies. In the face of adversity, resourceful leaders possess the cognitive competence to productively manage their thoughts, what they hold sway, and their expectations (Suryaningtyas, et al., 2019). Also, they demonstrate adequate affective capability by putting their emotional urgings in check; they do not allow their emotions to get the better of them when faced with uncertainties.

\section{Collaborative Management and Organizational Resilience}

Activating change that makes complex interactions among organizational members more resilient needs reprioritization in how people work together, organize, and invest and how they value and manage the organization. It takes multiple strands of activities, but there is structure. There are 'building blocks for resilience (Suryaningtyas, et al., 2019). Diversity - in value chains and markets, but also infrastructure and nature. With diversity, an enterprise can 
switch to an alternate supply chain for example in case of disruption, while diverse teams foster innovation and creativity. Diversity in for example energy supply or transportation systems buffers populations and the broader economy against disruption. Sustainable infrastructure and technologies - that are sustainable and robust, with wide tolerances and incorporating organizational system functions and that continue to operate despite fierce market competitions or market threat.

\section{Leadership Climate, Collaborative Management, and Organisational Resilience}

Recent climate research Chen and Bliese (2002) reveals how critical it is to scrutinize the effects of group-level leadership, which is acknowledging both group's means of and group dissimilarity in leadership. In line with research into organizational climate, we follow the terminology introduced by (Schneider, Salvaggio \& Subirats, 2002). Thus, the group means is the leadership climate level (the mean perception within a group) while low group variation of leadership implies leadership climate strength. The focus of this paper is on the moderating impact of leadership climate on collaborative management and organizational resilience, and the implication on employee climate perception. A leader needed to do strategic resilience to anticipate and prevent the crisis, and continuously doing changes whether or not there is a crisis. According to Carter and Greer (2013), the leadership climate should be encouraging and supported by employees. Transactional leadership is needed to execute organizational resilience because transformational leadership will make changes to the whole organization systems quickly and fine-tune to the changes in the outer environment accordingly. On the other hand, orientation on a day-to-day activity that follows the changes to achieve superior performance will keep transactional leadership remains. The leadership climate of an organization is effective and successful when the leaders or managers create a collaborative atmosphere where the employees and managers can do joint problem solving to be able to stand together and take necessary actions needed to face environmental and organizational changes, thereby strengthening resilience (Veiseh et al., 2014). 


\section{Empirical Review}

\begin{tabular}{|c|c|c|c|c|c|}
\hline S/No. & Author/Year & Country & Topic/Objective & Method Used & Findings \\
\hline 1. & $\begin{array}{l}\text { Thomson, } \\
\text { Perry and } \\
\text { Miller (2007) }\end{array}$ & Indiana & $\begin{array}{l}\text { An empirically validated } \\
\text { theory of collaboration, one } \\
\text { that can inform both theory } \\
\text { and practice, demands a } \\
\text { systematic approach to } \\
\text { understanding the meaning } \\
\text { and measurement of } \\
\text { collaboration. }\end{array}$ & $\begin{array}{l}\text { A mail questionnaire } \\
\text { sent to } 1382 \text { directors } \\
\text { of organisations that } \\
\text { participate in a large } \\
\text { national gervice } \\
\text { program provides the } \\
\text { basis for a higher } \\
\text { order confirmatory } \\
\text { factor analygis. }\end{array}$ & $\begin{array}{l}\text { The model that emerged from their } \\
\text { analysis demonstrated an overall } \\
\text { close fit with the empirical data and } \\
\text { the high, standardized gamma } \\
\text { coefficients estimated in the model } \\
\text { confirm that five key dimensions } \\
\text { contribute to an overall construct of } \\
\text { collaboration. }\end{array}$ \\
\hline 2. & $\begin{array}{l}\text { Akgunduz, } \\
\text { Bardakoglu } \\
\text { and Alkan } \\
(2015)\end{array}$ & Turkey & $\begin{array}{l}\text { A study to determine the } \\
\text { moderating role of job } \\
\text { resourcefulness under the } \\
\text { influence of work-family and } \\
\text { family-work life conflict on } \\
\text { the bumout levels of } \\
\text { employees. }\end{array}$ & $\begin{array}{l}\text { A hierarchical } \\
\text { regression analysis } \\
\text { was conducted to test } \\
\text { the hypotheses based } \\
\text { on the reliability and } \\
\text { validity of the scales. }\end{array}$ & $\begin{array}{l}\text { Resourcefulness reduces } \\
\text { detrimental effects of work-family } \\
\text { conflict on emotional exhaustion } \\
\text { and depersonalization. In addition, } \\
\text { results also indicate that job } \\
\text { resourcefulness reduces detrimental } \\
\text { effects of family-work conflict on } \\
\text { depersonalization. }\end{array}$ \\
\hline 3. & $\begin{array}{l}\text { Lei XIAO and } \\
\text { Huan CAO } \\
(2017)\end{array}$ & China & $\begin{array}{l}\text { The concept, measures and } \\
\text { integrated model of } \\
\text { organisational resilience. }\end{array}$ & $\begin{array}{l}\text { The model includes } \\
\text { lot of factors, } \\
\text { relations and } \\
\text { mechanisms. }\end{array}$ & $\begin{array}{l}\text { They found out that there is great } \\
\text { potential for future research within } \\
\text { the area of resilience. For } \\
\text { enterprises, they should be aware of } \\
\text { the challenges of uncontinuous and } \\
\text { dismuptive environment and build } \\
\text { resilience capability or prepare to } \\
\text { do something in advance. }\end{array}$ \\
\hline 4. & $\begin{array}{l}\text { Pavard, } \\
\text { Dugdale, } \\
\text { Saoud, Darcy } \\
\text { and Salembier } \\
\text { (2008) }\end{array}$ & France & $\begin{array}{l}\text { A paper to make a conceptual } \\
\text { distinction between the } \\
\text { notions of robustness and } \\
\text { resilience. }\end{array}$ & $\begin{array}{l}\text { Examples from } \\
\text { emergency and crisis } \\
\text { management }\end{array}$ & $\begin{array}{l}\text { Emergent and self-organised } \\
\text { regulation can play a critical role in } \\
\text { achieving robust socio-technical } \\
\text { systems }\end{array}$ \\
\hline 5. & $\begin{array}{l}\text { Capano and } \\
\text { Woo (2016) }\end{array}$ & China & $\begin{array}{l}\text { An investigation on } \\
\text { Resilience and robustness are } \\
\text { exciting concepts for policy } \\
\text { researchers. }\end{array}$ & $\begin{array}{l}\text { A review definitions } \\
\text { of these concepts and } \\
\text { the primary } \\
\text { theoretical and } \\
\text { empirical challenges } \\
\text { presented by } \\
\text { resilience and } \\
\text { robustness as lenses } \\
\text { for improving the } \\
\text { understanding of } \\
\text { policy process and } \\
\text { policy degien. }\end{array}$ & $\begin{array}{l}\text { Despite its diffusion and 'charme', } \\
\text { resilience does not appear to be } \\
\text { useful and may be misleading, } \\
\text { whereas robustness exhibits great } \\
\text { potential with respect to both } \\
\text { analysis and design. }\end{array}$ \\
\hline
\end{tabular}

\begin{tabular}{|c|c|c|c|c|c|}
\hline 6. & $\begin{array}{l}\text { Oppong } \\
\text { Banahene, } \\
\text { Anvuur and } \\
\text { Dainty (2014) }\end{array}$ & Portsmouth & $\begin{array}{l}\text { Investigation on } \\
\text { Conceptualising } \\
\text { organisational resilience: An } \\
\text { investigation into project } \\
\text { organising. }\end{array}$ & $\begin{array}{l}\text { Systematically } \\
\text { reviewing and } \\
\text { relating the lines of } \\
\text { literature on } \\
\text { organisational } \\
\text { resilience and project } \\
\text { organising. }\end{array}$ & $\begin{array}{l}\text { The investigation refined the } \\
\text { research necessary to develop the } \\
\text { concepts so as they respond to the } \\
\text { challenges of project-based } \\
\text { working. }\end{array}$ \\
\hline 7. & $\begin{array}{l}\text { Suryaningtyas, } \\
\text { Malang, Eka, } \\
\text { and Malang } \\
(2019)\end{array}$ & Indonesia & $\begin{array}{l}\text { A study aimed to contribute } \\
\text { to knowledge by } \\
\text { investigating the relationship } \\
\text { between organisational } \\
\text { resilience and organisational } \\
\text { performance both directly } \\
\text { and indirectly, with resilient } \\
\text { leadership and organisational } \\
\text { culture play mediating roles. }\end{array}$ & $\begin{array}{l}\text { Structural Equation } \\
\text { Modeling. }\end{array}$ & $\begin{array}{ll}\text { The findings reveal } & \text { that } \\
\text { organisational resilience } & \text { was } \\
\text { positively associated } & \text { with } \\
\text { organisational performance. } & \end{array}$ \\
\hline
\end{tabular}




\section{Hypotheses}

From the above questions, the succeeding null hypotheses were formulated:

$\mathbf{H}_{\text {O1: }}$ : There is no significant relationship between collaborative management and robustness of oil and gas firms in Rivers State.

$\mathbf{H}_{\mathbf{O} 2}$ : There is no significant relationship between collaborative management and resourcefulness of oil and gas firms in Rivers State.

Ho3: Leadership climate does not moderate the relationship between collaborative management on organizational resilience of oil and gas firms in Rivers State.

\section{Methodology}

This study adopts the quasi-experimental research design, specifically, the cross-sectional research design. The population is made of managers and supervisors of oil and gas firms in Rivers State. These firms were carefully chosen because most of them have been in operation for more than six years, the quality services they offer, and the number of staff under their employ. Statistically, a cross-sectional depiction of the assessment by contact showed an aggregate of 72 managers, supervisors, and HODs of these firms, which makes up the accessible population. Copies of the survey instrument were administered accordingly. In determining the sample size, we adopted the census technique. The census technique has to do with adopting the entire population as the sample size. This amounted to 72 managers, supervisors, and HODs surveyed. This decision was taken because the population is relatively small. Furthermore, the convenience sampling technique (a non-probability sampling technique), was used. This sampling technique was preferred as a result of the level of accessibility and availability of the size of the population.

\section{Results}

The entire $72(100 \%)$ managers, supervisors, and HODs were administered copies of the survey instruments accordingly. Out of which, 61 (85\%) copies of the questionnaire were retrieved, among which, 3 (4\%) copies were wrongly filled, and $58(81 \%)$ copies were valid and used to analyze the data.

$\mathrm{HO}_{1:}$ There is no significant relationship between collaborative management and robustness of oil and gas firms in Rivers State.

Collaborative Management and Robustness

\section{Correlations}

\begin{tabular}{|lll|r|r|}
\hline & & Collaborative & Robustness \\
Management & \\
\hline & \multirow{2}{*}{ Collaborative Management } & Correlation Coefficient & 1.000 & $\mathbf{0 . 4 7 2}$ \\
\cline { 3 - 4 } Spearman's rho & & Sig. (2-tailed) & 0 & $\mathbf{0 . 0 0 5}$ \\
& & $\mathrm{N}$ & 58 & 58 \\
& & Correlation Coefficient & $\mathbf{0 . 4 7 2}$ & 1.000 \\
& Robustness & Sig. (2-tailed) & $\mathbf{0 . 0 0 5}$ & 0 \\
& & $\mathrm{~N}$ & 58 & 58 \\
\hline
\end{tabular}

Source: Author's Field Survey (2021) - SPSS version 21 output extracts

The result of the analysis shows a significant level $\mathrm{p}<0.05(0.005<0.05)$, rho $=0.472$ between collaborative management and robustness. Specifically, the degree of relationship is 
47\% (approximately 50\%), which is fairly significant. This means that there is a fairly significant relationship between collaborative management and robustness. The null hypothesis is rejected, and we restate that there is a significant relationship between collaborative management and robustness.

$\boldsymbol{H O}_{2}$ : There is no significant relationship between collaborative management and resourcefulness of oil and gas firms in Rivers State.

\section{Collaborative management and Resourcefulness}

Correlations

\begin{tabular}{|lll|r|r|}
\hline & & Collaborative & Resourcefulness \\
Management & \\
\hline & \multirow{2}{*}{ Collaborative Management } & Correlation Coefficient & 1.000 & $\mathbf{0 . 5 2 0}$ \\
\cline { 3 - 5 } Spearman's rho & & Sig. (2-tailed) & 0 & $\mathbf{0 . 0 0 0}$ \\
& & $\mathrm{N}$ & 58 & 58 \\
& & Correlation Coefficient & $\mathbf{0 . 5 2 0}$ & 1.000 \\
& Resourcefulness & Sig. (2-tailed) & $\mathbf{0 . 0 0 0}$ & 0 \\
& & $\mathrm{~N}$ & 58 & 58 \\
\hline
\end{tabular}

Source: Author's Field Survey (2021) - SPSS version 21 output extracts

The result of the analysis shows a significant level $\mathrm{p}<0.05(0.000<0.05)$, rho $=0.520$ between collaborative management and resourcefulness. Specifically, the degree of relationship is $52 \%$, which is significant. This means that there is a significant relationship between collaborative management and robustness. The null hypothesis is rejected, and we restate that there is a significant relationship between collaborative management and resourcefulness.

HO $_{3}$ Leadership climate does not significantly moderate the relationship between collaborative management and organizational resilience of oil and gas firms in Rivers State.

\begin{tabular}{|c|c|c|c|c|}
\hline \multicolumn{5}{|c|}{ Correlations } \\
\hline \multicolumn{3}{|c|}{ Control Variables } & $\begin{array}{l}\text { Collaborative } \\
\text { Management }\end{array}$ & $\begin{array}{c}\text { Organizational } \\
\text { Resilience }\end{array}$ \\
\hline \multirow{8}{*}{- none- $^{\mathrm{a}}$} & \multirow{4}{*}{$\begin{array}{l}\text { Collaborative } \\
\text { Management }\end{array}$} & Correlation & 1.000 & 0.459 \\
\hline & & Significance (2- & 0 & 0.000 \\
\hline & & tailed) & & \\
\hline & & Df & 0 & 56 \\
\hline & \multirow{4}{*}{$\begin{array}{l}\text { Organizational } \\
\text { Resilience }\end{array}$} & Correlation & 0.459 & 1.000 \\
\hline & & Significance (2- & 0.000 & 0 \\
\hline & & tailed) & & \\
\hline & & Df & 56 & 0 \\
\hline \multirow{8}{*}{$\begin{array}{l}\text { Leadership } \\
\text { climate }\end{array}$} & \multirow{4}{*}{$\begin{array}{l}\text { Collaborative } \\
\text { Management }\end{array}$} & Correlation & 1.000 & 0.403 \\
\hline & & Significance (2- & 0 & 0.002 \\
\hline & & tailed) & & \\
\hline & & Df & 0 & 55 \\
\hline & \multirow{4}{*}{$\begin{array}{l}\text { Organizational } \\
\text { Resilience }\end{array}$} & Correlation & 0.403 & 1.000 \\
\hline & & Significance (2- & 0.002 & 0 \\
\hline & & tailed) & & \\
\hline & & Df & 55 & 0 \\
\hline
\end{tabular}

a. Cells contain zero-order (Pearson) correlations.

Source: Author's Field Survey (2021) - SPSS version 21 output extracts 
The study observed, from the probability level of 0.002 , that leadership climate significantly moderates the existent relationship between collaborative management and organizational resilience. The positive correlation value of 0.403 shows that an increase in the intensity of the leading climate is likely to subsequently increase the existing relationship between collaborative management and organizational resilience by up to $40.3 \%$.

\section{Discussion}

Outcomes from the analysis revealed:

\section{Collaborative Management, Robustness, and Resourcefulness}

The bivariate hypotheses between governance, robustness, and resourcefulness reveal a noteworthy affiliation between the three variables. The Spearman correlation coefficient revealed the $\mathrm{p}$-value $-0.005<0.05(\mathrm{p}=0.0050 .05)$, meaning governance has an ample link with robustness and resourcefulness. The consequence of the correlation coefficient (rho) $=$ 0.472, indicating a useful degree of association amid them. Implying that $47.2 \%$ total deviation in the robustness and resourcefulness of a business outfit could be accounted for by governance. These findings seem to tally with Dabor, Isiavwe, and Ajagbe's (2015) view that governance can potentially enhance robustness and resourcefulness through increased performance.

\section{Leadership Climate, Collaborative Management, and Organisational Resilience}

The multivariate analysis of the moderating sway of leadership climate on the link between collaborative management and Organisational resilience exposed a substantial moderating effect of leadership climate. This means that leadership climate positively influences the relationship between the predictor and criterion variables, Collaborative management and Organisational resilience. All null hypotheses were rejected and the alternate accepted given the fact that the p-value of 0.002 was less than the level of significance $(0.05)$. The positive correlation value of 0.403 shows that an increase in the intensity of leadership climate is likely to subsequently increase the existing relationship between collaborative management and organizational resilience by up to $40.3 \%$. These findings agree with that of Mark (2016) and Hurley (2011) who all noted that a good leadership climate could induce high-level collaboration in the firm.

\section{Conclusion}

Imbibing collaborative efforts in the management of organizational activities is a key factor in a developing economy such as Nigeria. At the moment, the oil and gas industry is a saving element upon which the budgetary items are adequately financed. Based on the sensitive nature of these factors, it is pertinent for organizations that are operating within this industry to be robustly and resourcefully resilient on all sides since they pay taxes to the government and contribute to the gross domestic product (GDP). Based on these submissions, spelled-out collaborative efforts could be instituted in terms of governance, autonomy, mutuality, and norms of reciprocity to adequately address issues that may arise due to internal and external disturbances. Conclusively, a sound leadership climate can change the direction of any organization towards achieving its stated goals. This means a good leadership climate could induce high-level firm alliance. Organizational leadership climate is a composition variable 
that can be brought to bear in proffering varying solutions to the underlying issues in any organization.

\section{Recommendations}

As a fall out from the analysis and deliberations, it is recommended that:

i. Collaborative management encourages positive behaviors towards robustness. Hence, management ought to take decisional actions to increase awareness and improve productivity towards developing timely diverse solutions in handling organizational challenges.

ii. Collaborative management improves top-level decision-making to enhance resourcefulness. Therefore, management should encourage employees to make personal decisions about the disturbances and complex problems they face in their job towards preserving their position in the industry.

iii. Organizational leadership should build a climate designed to encourage robustness and resourcefulness as that will induce the needed growth towards its desired heights to foster resilience. 


\section{References}

Annarelli, A. \& Nonino, F. (2016). Strategic and operational management of organizational resilience: Current state of research and future directions. Omega, 62, 1-18.

Ashill, N. J., Rod, M., Thirkell, P., \& Corruthers, J. (2009). Job resourcefulness, symptoms of burnout and service recovery performance: An examination of call center frontline employees. Journal of Service Marketing, 23(5), 338-350.

Capano, G., \& Woo, J. J. (2016). Resilience and robustness in policy design: A critical Appraisal. Policy Sci. 21(3), 243-255. https://doi.org/10.1007/s11077-016-9273-x

Carter, S., \& Greer, C. (2013). Strategic leadership: Values, styles, and organizational performance. Journal of Leadership \& Organizational Studies, 20, 375-393. https://doi.org/10.1177/1548051812471724

Chen, G., \& Bliese, P. D. (2002). The role of different levels of leadership in predicting selfand collective efficacy: Evidence for discontinuity. Journal of Applied Psychology, $87,549-556$.

Dabor, A. O. Isiavwe, D. T. Ajagbe, M. A. (2015). Impact of corporate governance on firms' performance. International Journal of Economics, Commerce and Management United Kingdom, 3(6). 23-28.

Emmitt, S (2010). Managing Interdisciplinary Projects. Oxon: Spon Press.

Frynas, J.G. (1999). Oil in Nigeria: Conflict and litigation between oil companies and village communities. Foreign Affairs. https://www.semanticscholar.org/paper/Oil-inNigeria\%3A-conflict-and-litigation-between-oil Ite/ad4f602afd2a377600c61a23a31150ebb4b8db62

Gallopın, G. C. (2006) Linkages between vulnerability, resilience, and adaptive capacity. Global environmental change, 16(3), 293-303.

Giezen, M. (2013) Adaptive and strategic capacity: Navigating megaprojects through uncertainty and complexity. Environment and Planning B: Planning and Design, 40(4), 723-741.

Haight, B. K., Barbara, B. E., Courts, N. F. \& Tesh, A. S. (2002). Thriving: A life span theory. Journal of Gerontological Nursing, 28(3), 14-22.

Harris, E. G., Artis, A. B., Waters, J. H., \& Licata, J. W. (2006). Role stressors service worker job resourcefulness and job outcomes: An empirical analysis. Journal of Business Research, 59(4), 407-415.

Holling, C.S (1973). Resilience and stability of ecological systems. Annual Review of Ecology and Systematics, 4, 1-23.

Hurley, T. J (2011). Collaborative leadership: Engaging collective intelligence to achieve results across organizational boundaries. Oxford Leadership, White Paper.

International Energy Agency (2019). Oil and gas: Our exploration and production operations. Explore and Produce. 
Jeremiah, K. (2019). Nigeria's crude oil production to witness eight percent decline. The Guardian. Retrieved from https://guardian.ng/business-services/nigerias-crude-oilproduction-to-witness-eight-per-cent-decline/

Lengnick-Hall, C. A., Beck, T. E., \& Lengnick-Hall, M. L. (2011). Developing a capacity for organizational resilience through strategic human resource management. Human Resource Management Review, 21(3), 243-255.

Lengnick-Hall, C.A., \& Beck, T.E., (2009). Resilience capacity and strategic agility: Prerequisites for thriving in a dynamic environment. Working Paper, University of Texas.

Licata, J. W., Mowen, J. C., Harris, E. G., \& Brown, T. J. (2003). On the trait antecedents and outcomes of service worker job resourcefulness: A hierarchical model approach. Journal ofAcademy of Marketing Science, 31(3), 256-271.

Mark, S. (2016). Collaboration for resilience: How collaboration among business, government and NGOs could be the key to living with turbulence and change in the 21st Century. Gland.

Madni, A. M. (2007) Designing for resilience. ISTI lecture notes on advanced topics in systems engineering. Journal of Business and Management, 16(2), 7-16.

McManus, S. (2008). Organizational resilience in New Zealand. Unpublished Ph.D. Thesis, Civil Department, University of Canterbury

Powell, W W, Koput, K W, Smith-Doerr, L, \& Owen-Smith, J (1999). Network position and firm performance: Organisational returns to collaboration in the biotechnology industry. Research in the Sociology of Organisations, 16(1), 129-159.

Sanaghan, P., \& Aronson, N., (2009). Deep lessons on collaboration: how collaboration really works. Bloomington: Xlibris Corp.

Schneider, B. (2000). The psychological life in organizations. In N. M. Ashkanasy, C. P. M. Wilderom, \& M. F. Peterson (Eds.), Handbook of organizational culture and climate. Thousand Oaks, CA: Sage.

Schneider, B., Salvaggio, A. N., \& Subirats, M. (2002). Climate strength: A new direction for climate research. Journal of Applied Psychology, 87, 220-229.

Somers, S. (2009). Measuring resilience potential: An adaptive strategy for organizational crisis planning. Journal of Contingencies and Crisis Management, 17(1). https://doi.org/10.1111/j.1468-5973.2009.00558.x.

Sutcliffe, K., Vogus, T., \& Dane, E. (2016). Mindfulness in organizations: A cross-level review. Annual Review Organisational Psychology Organisational Behavior, 3, pp. $55-81$.

Suryaningtyas, D., Malang, S.A., Malang T., Eka A., Malang, I. D. W. (2019). Organizational resilience and organizational performance: examining the mediating roles of resilient leadership and organizational culture. Academy of Strategic Management Journal, 18(2) 1-7. 
Tende, F.B., Achebelema, D.S. \& Kpurubu, H.B. (2018). Impact of entrepreneurial spirit on resilience of small and medium-size agribusinesses in Nigeria. Sumerianz Journal of Business Management and Marketing, 1(3), 79-87

Thomson, A. M., Perry, J. L., \& Miller, T. K. (2007). Conceptualizing and measuring collaboration. Journal of Public Administration Research and Theory, 1-34.

Thomson, A.M. (1999). AmeriCorps organizational networks: Six case studies of Indiana AmeriCorps programs. National Service Fellows Program. Report for the Corporation for A.H.

Thomas, D. (1995). Niger Delta oil production, reserves, field sizes assessed: Industry briefs. Oil and Gas Journal 85, 13 -25

Umoh, I.G., Amah, E., \& Wokocha, H.I (2014). Management development and organizational resilience. A case study of some selected manufacturing firms in Rivers State. Nigeria. Journal of Business and Management, 16 (2), 7-16.

Veiseh, S., Mohammadi, E., Pirzadian, M., \& Sharafi, V. (2014). The relation between transformational leadership and organizational culture. Journal of Business Studies Quarterly, 5, 113-124. Retrieved from http://jbsq.org

Weir, C. \& Laing, D. (2001). Governance structures, director independence, and corporate performance in the UK. European Business Review, 13(2), 86-94. 